\title{
A Preliminary Comparison of Two Caddo Mound Sites in Southwest Arkansas
}

Mary Beth D. Trubitt

Arkansas Archeological Survey, HSU Research Station

Follow this and additional works at: https://scholarworks.sfasu.edu/ita

Part of the American Material Culture Commons, Archaeological Anthropology Commons, Environmental Studies Commons, Other American Studies Commons, Other Arts and Humanities Commons, Other History of Art, Architecture, and Archaeology Commons, and the United States History Commons

Tell us how this article helped you.

This Article is brought to you for free and open access by the Center for Regional Heritage Research at SFA ScholarWorks. It has been accepted for inclusion in Index of Texas Archaeology: Open Access Gray Literature from the Lone Star State by an authorized editor of SFA ScholarWorks. For more information, please contact cdsscholarworks@sfasu.edu. 


\section{A Preliminary Comparison of Two Caddo Mound Sites in Southwest Arkansas}

Creative Commons License

(c) (i) (8)

This work is licensed under a Creative Commons Attribution-NonCommercial 4.0 International License 


\title{
A Preliminary Comparison of Two Caddo Mound Sites in Southwest Arkansas
}

\author{
Mary Beth Trubitt \\ Arkansas Archeological Survey, HSU Research Station
}

Previous Arkansas Archeological Survey excavations at the Hedges site in the Ouachita River valley and the Hughes site in the Saline River valley uncovered evidence of burned structures adjacent to the mounds. An overview of the artifact analyses indicates that the sites were roughly contemporaneous, with intensive use by ancestral Caddo Indians during the Late Caddo period, between the AD 1400s and 1600s. This presentation summarizes the research findings to emphasize comparisons in timing, activities, and community plans.

\section{Introduction}

In a previous study of Caddo architecture (Trubitt 2009), I highlighted several dimensions of variation: circular or straight-sided structures; mound, near-mound, or non-mound location; buildings burned or unburned after use; and if burned, covered with "clean" earth or with midden debris. At that time, I saw similarities in two contemporaneous Caddo mound sites located in adjacent river drainages in southwest Arkansas that would benefit from further comparison. I and my assistants and lab volunteers have concluded analyses of artifacts from Ann Early's excavations at Hedges (3HS60), a site in the Ouachita River valley, and from my excavations at Hughes (3SA11), located in the Saline River valley (Figure 1). At both sites, excavators uncovered stratified deposits next to the main mounds that included burned buildings covered with midden deposits with ceramic sherds, chipped stone tools and debris, animal bone, and charred plant remains. While the full monograph is not yet complete, this paper summarizes highlights of the artifact analyses to show similarities in dating and activity patterns at these two Late Caddo period communities.

\section{Excavations at Hedges and Hughes}

In 1973 and 1974, Ann Early led a brief Arkansas Archeological Survey test excavation project at the Hedges site in Hot Spring County (Early 1974). Fieldwork included mapping two low mounds (Mound A, an elongated oval platform measuring $42 \times 25 \times 2 \mathrm{~m}$, and Mound B, a low conical burial mound eroded by the river). Conversations with local collectors indicated

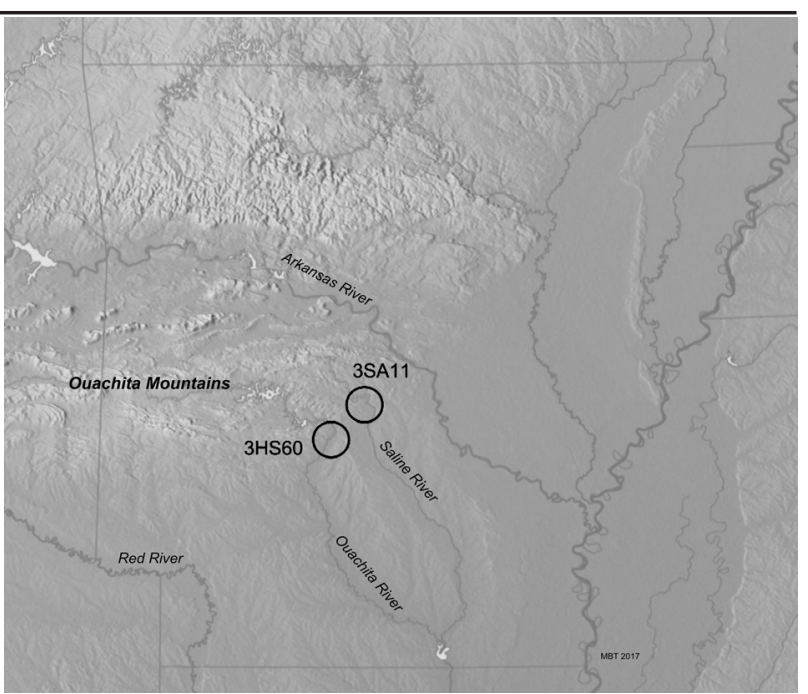

Figure 1. Location of 3HS60 (Hedges) in Arkansas's Ouachita River valley and 3SA11 (Hughes) in the Saline River valley (base map from Tom Patterson, Physical Map of the Coterminous United States).

at least three cemetery areas as well (Figure 2). Auger testing showed deep midden deposits south and west of Mound A.

Subsequent excavations south and west of Mound A included Test Pit 1 (a 2 × 2 m unit), a Block Excavation (of six 2 × 2 m units), and a Trench (1 x $6 \mathrm{~m}$ ). While no complete structures were exposed, archaeologists uncovered stratified deposits with burned cane and thatch, ash, daub, and post molds in all three excavation areas (Figure 3). The $90 \mathrm{~cm}$ of stratified deposits in Test Pit 1 included Feature 1 with patches of burned cane, thatch, bark, and wood, and scorched sand, ash, and daub. Residues of a second burned structure were found below that (as stratum 20, burned daub and floor deposit with post molds that cut into the underlying stratum 21). In the Block Excavation, a 


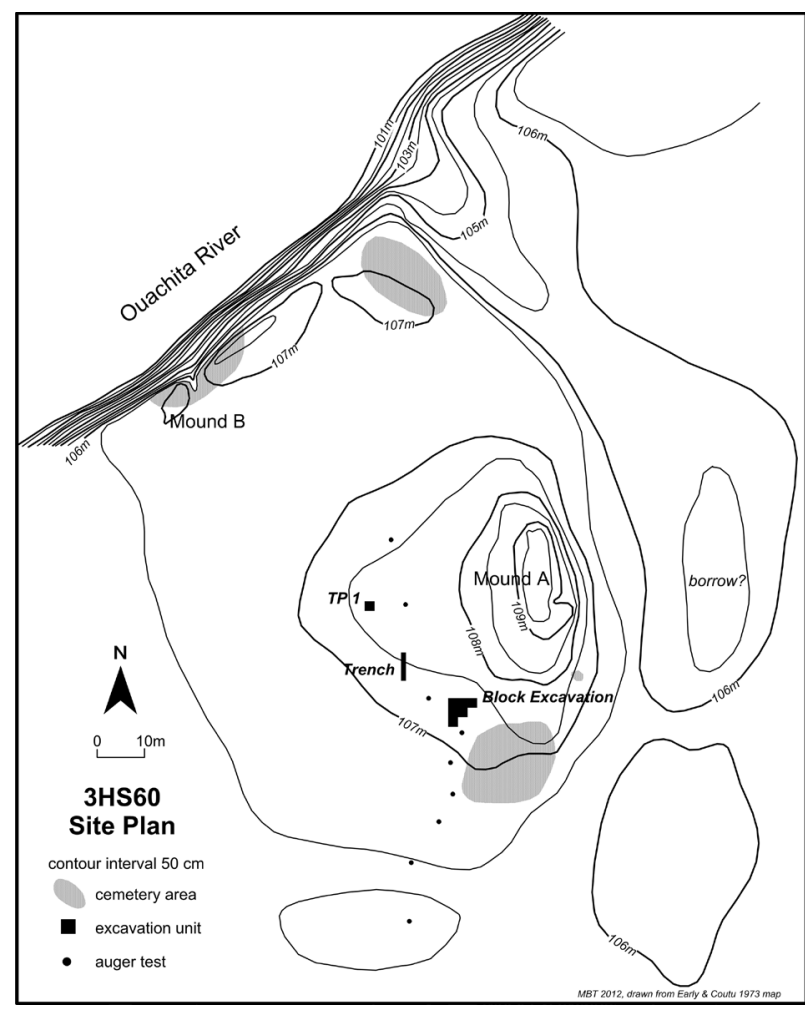

Figure 2. Hedges site plan (after Early and Coutu 1973 field drawing).

midden deposit was uncovered below the plow zone. Below the midden was Feature 4, a daub and charcoal concentration with post molds, interpreted as a burned structure. Another lower burned structure (Feature 6) was identified in one unit as a red clay lens (stratum 8) with associated post molds that cut into the underlying subsoil. Midden deposits and burned soil were also uncovered in the Trench, interpreted as the remains of a burned structure (Feature 5) with one or two burned floors and an ash lens. A lower burned floor was exposed but not excavated at about $60 \mathrm{~cm}$ below surface. The elevated area next to the west side of Mound A (shown by the 107 and $107.5 \mathrm{~m}$ contours) represents an artificial buildup of deposits as burned structures were covered by midden deposits.

Based on the artifacts, ancestral Caddo Indians used the site during the Mid-Ouachita and Social Hill phases of the Late Caddo period, ca. A.D. 1400-1650. Ann Early (1993:116; 2002) later used Hedges material in her definition of the Social Hill phase. Absolute dates from the site are few. Dan Wolfman $(1982,1990)$ published results of archaeomagnetic samples from 15 sites in southwest Arkansas as part of his research

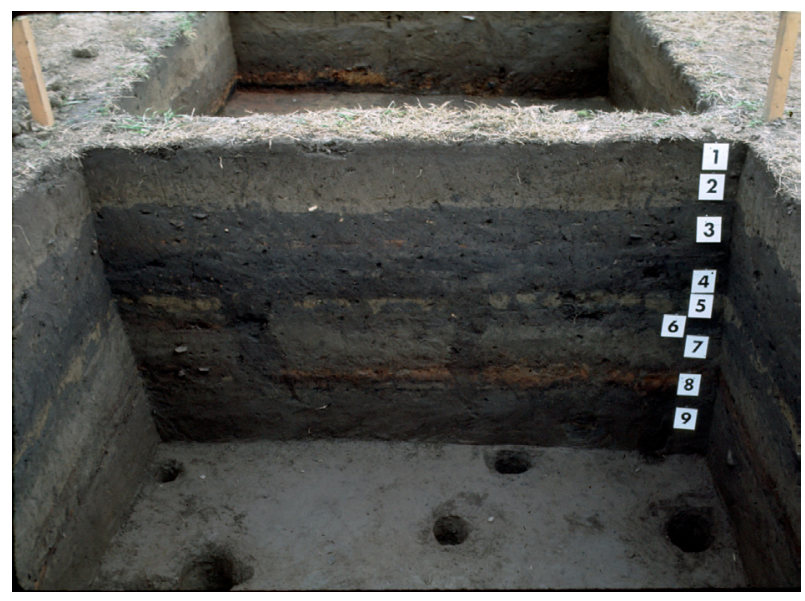

Figure 3. East wall profile, Hedges Block Excavation TU3, December 1973 (Arkansas Archeological Survey photograph).

to develop a regional "polar curve" and extend the utility of archaeomagnetic dating in archaeology. $\mathrm{He}$ calculated the resulting date from a burned structure floor (Feature 5) at Hedges at A.D. 1450-1535. More recently, we directly dated charred maize kernels from the Block Excavation midden deposit (above Feature 4) using the accelerator mass spectrometry technique to cal A.D. 1650-1660 (Trubitt 2012a).

The Hughes site in Saline County is near the eastern edge of the Caddo archaeological area. Archaeologists - and artifact collectors - have known about the site for over a hundred years. It was visited by Edward Palmer in 1883 as part of the Smithsonian Institution's Mound Survey (Jeter 1990:293-296; Thomas 1894:246-247). Palmer's description of daub and charcoal/ash deposits indicate there must have been at least one burned structure in the site's large twostage mound. Other lower mounds had apparently been leveled even before Palmer's visit; the property was part of a nineteenth-century farm. Hughes was placed on the National Register of Historic Places in 1985. While on private land and protected by the property owner, unauthorized digging into the mound has been a concern.

I conducted excavations at Hughes as part of the 2002 Henderson State University/University of Arkansas archaeological field school. Students mapped the site with an electronic total station, showing the large two-stage mound as a $35 \times 55 \times 5.5$ $\mathrm{m}$ construction (Figure 4). Because of the tree cover at the site, we used systematic shovel testing to identify 


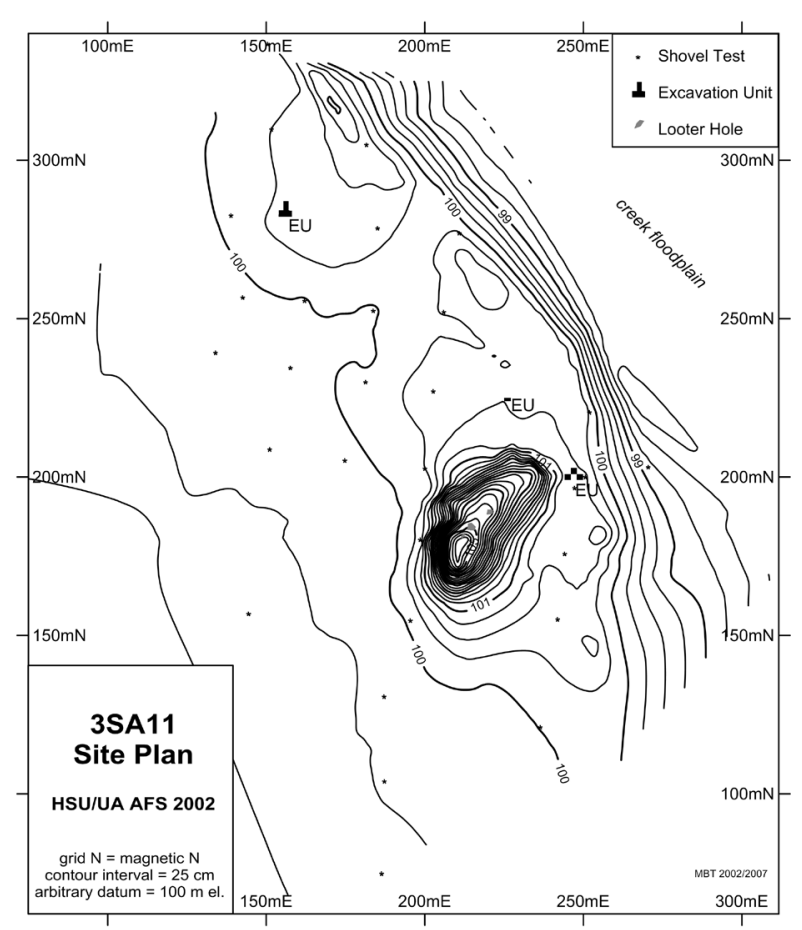

Figure 4. Hughes site plan.

spatial patterning within the site. Shovel testing across about 3.8 hectares showed artifact concentrations and uncovered features in two areas. We investigated these further with excavation units. In a 4 x 5 m excavation block on the north edge of the site, students uncovered a large burned clay hearth (Feature 1; Figure 5). This was likely part of a structure not fully exposed by our fieldwork. A 1 x 2 m excavation unit north of the mound sampled a dense area of midden. Northeast and near the mound, excavators uncovered stratified deposits in three $2 \times 2 \mathrm{~m}$ units, with burned timbers, burned earth and daub, and quantities of ceramic sherds, chipped stone debris, and animal bone. Although no post patterns were seen, the burned clay, daub, charcoal and burned timbers (Feature 2/3/4, Feature 7, and Feature 8/16) were interpreted as a series of burned structures (Trubitt 2009, 2012b). Three charred wood samples were dated using the conventional radiocarbon technique. The lowest structure (Feature 8/16) dated to cal A.D. 12701390 while the overlying one (Feature 7) dated to cal A.D. 1450-1620 (Trubitt 2012b). As at Hedges, the elevated area northeast of the mound (100.5 m contour) represents an artificial buildup of midden deposits covering burned structures.

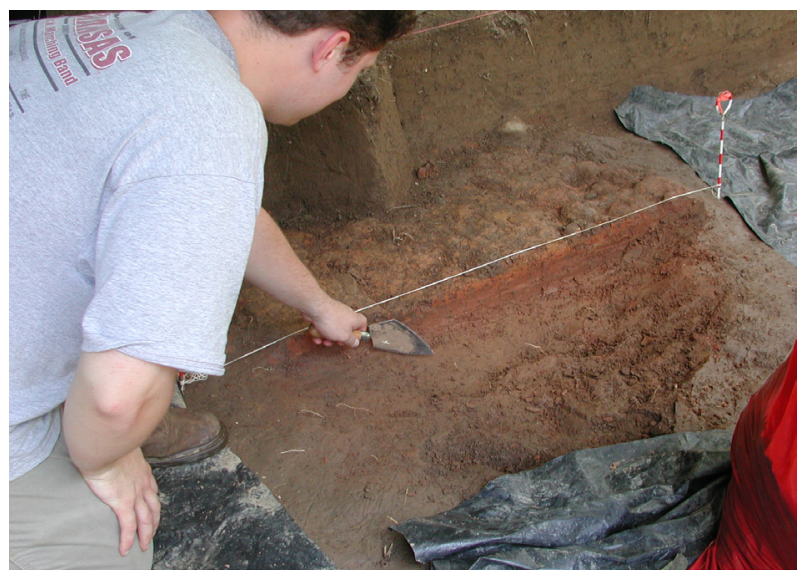

Figure 5. Sectioning Feature 1, EU N282E154-156, Hughes site, July 2002 (Arkansas Archeological Survey photograph).

\section{Artifact Analyses}

Our analyses of artifacts from Hedges and Hughes (Table 1) have had two goals: first, to place the use of these communities in a temporal and cultural framework; and second, to gain a better understanding of activity patterns in these near-mound areas.

Chipped stone included tools and chipping debris. I examined arrow points to identify types that have served as "time markers" elsewhere. There were points and point fragments made from novaculite and chert at both sites (Figure 6). Bassett were the most common arrow point style at Hedges. These are basalnotched triangular points with prominent barbs and small rounded or pointed stems. The predominant arrow point form at Hughes was the Maud type, a triangular point with a concave base, in both the un-notched var. Maud and the side-notched var. Hopper. Both types occur on Late Caddo sites in east Texas, northwest Louisiana, and southwest Arkansas (e.g., Kay 1984:184187; Kelley 1997:65-66; McKinnon 2017:91-102; Perttula 2017:206-207; Webb 1959:162-163). In the Ouachita River valley, Bassett points have been found with late Mid-Ouachita phase ceramic types, estimated to date to the late fifteenth century, and Maud points have been found with Buckville and Social Hill phase ceramics, estimated to date to the fifteenth to early seventeenth century (Early 1988:107-109; 1993:122123; 2002; Trubitt 2012b). In addition, there were several antler projectile points from the sites (Figure 7). Antler tine points are not commonly preserved on Caddo sites, but they have been found in Belcher and 


\begin{tabular}{|l|r|r|r|r|r|}
\hline & Hedges (3HS60) & & Hughes (3SA11) \\
\hline & $\mathrm{Ct}$ \# & Wt g & $\mathrm{Ct \#}$ & Wt g \\
\hline Ceramics & 7611 & 40100.7 & 13703 & 23669.0 \\
\hline Chipped Stone & 3767 & 10602.0 & 3396 & 3301.4 \\
\hline Ground Stone & 24 & 5117.2 & 44 & 5186.8 \\
\hline Faunal & 3454 & 7677.7 & 5660 & 6795.2 \\
\hline Floral/C14 & 227 & 9137.4 & 3689 & 4559.0 \\
\hline Daub/Burned Clay & 513 & 4501.0 & 8628 & 9992.8 \\
\hline Historic/Modern & 199 & 440.4 & 2592 & 8528.3 \\
\hline Rocks/Minerals & 950 & 19336.6 & 88 & 1113.2 \\
\hline Totals: & 16745 & 96913.0 & 37800 & 63145.7 \\
\hline
\end{tabular}

Note: Totals include 1973 and 1974 testing at Hedges, and 2002 shovel testing, pothole cleanup, and test excavation at Hughes. The rocks/minerals category from Hughes represents the curated sample.

Table 1. Artifact Totals.

Chakanina phase contexts in the Red River valley (e.g., Kay 1984:191-192; Kelley 1997:87-89; McKinnon 2017:46; Webb 1959:167-169).

There was well-preserved animal bone found at both sites. None of the faunal material from Hedges has been formally analyzed, but Lucretia Kelly analyzed a faunal sample from Hughes in 2011. She found that mammals made up the largest category, with deer and squirrels most common. Residents used turtles and mussels but there were relatively few bones from birds and fish. There was a predominance of terrestrial animals as compared with aquatic ones. In addition to the bone or antler points, there are several other worked bone tools in the form of antler tine knapping tools and pierced mussel shell hoes from Hedges and Hughes.

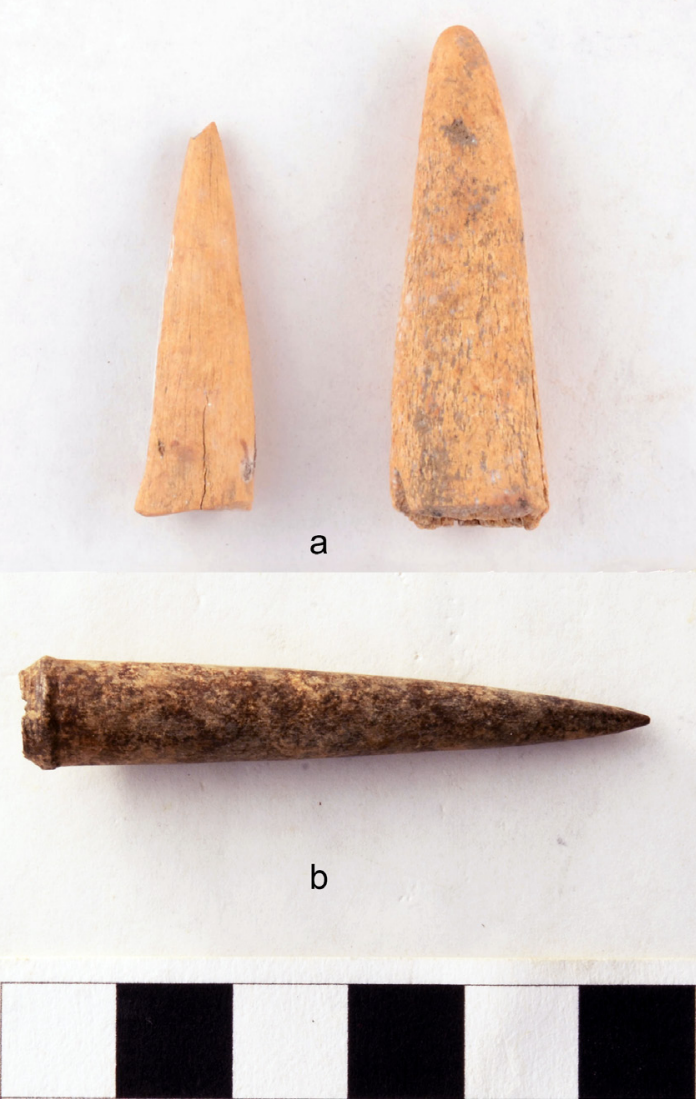

Figure 7. Bone points: (a) Hedges; (b) Hughes (Arkansas Archeological Survey photographs).

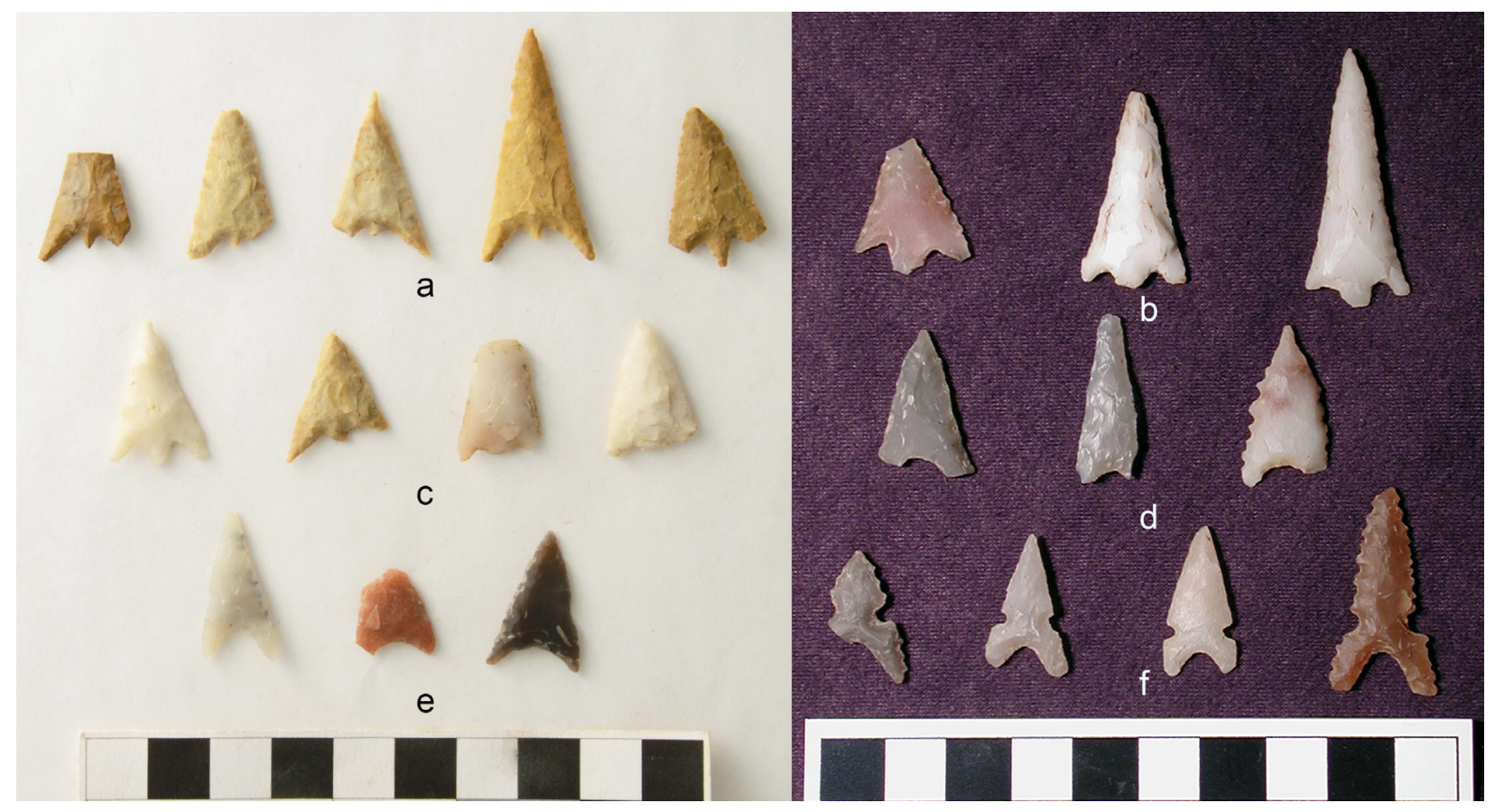

Figure 6. Sample of arrow points from Hedges (left) and Hughes (right): (a-c) Bassett; (d-e) Maud var. Maud; (f) Maud var. Hopper (Arkansas Archeological Survey photographs). 


\begin{tabular}{l|r|r|r|r|r|r|r|r|}
\hline & \multicolumn{7}{|c|}{ 3HS60 } & \multicolumn{4}{|c|}{ 3SA11 } \\
\hline & Ct. & Wt. (g) & Ct. \% & Wt. \% & Ct. & Wt. (g) & Ct. \% & Wt. \% \\
\hline Shell & 4768 & 19528.5 & 63 & 56 & 3710 & 14570.4 & 87 & 88 \\
\hline Grog & 2310 & 12126.3 & 30 & 34 & 408 & 1557.2 & 10 & 9 \\
\hline Other/Mixed & 533 & 3515.4 & 7 & 10 & 126 & 505.9 & 3 & 3 \\
\hline Total & 7611 & 35170.2 & 100 & 100 & 4244 & 16633.5 & 100 & 100 \\
\hline
\end{tabular}

Table 2. Sherd Temper Comparisons.

Several ornaments were found, including a bone hairpin from Hedges, and three fragments of worked bone (earspool fragments) from Hughes. Other artifacts included a ceramic disk fragment, a drilled black stone bead, and a drilled and polished triangular ornament of black stone from Hedges. We can interpret that crafting took place here, based not only by the ornaments but by the presence of several small chipped stone drill bits at both sites (see also Kelley 1997:68-69).

Ceramic sherds formed the largest category of artifacts recovered during excavations at both sites. Two whole vessels (a jar and a seed jar) have been reconstructed from sherds found in the floor debris from the Feature 1 structure at Hedges (Figure 8). Most of the pottery from both sites took the form of sherds. Temper categories included shell, grog, and a mixed/ other category (shell+grog was identified as a separate category only for the Hedges decorated and rim sherds, resulting in a higher proportion of "mixed/other" tempers there). Shell was used to temper a majority of sherds at both sites, but a larger proportion of grogtempered sherds came from Hedges (Table 2). Adding shell as a temper was an innovation that occurred late in the Caddo period, and its appearance has been used as a "time marker" (Perttula et al. 2011).

Using stratigraphic information from both sites, we can see evidence for this increased use of shell as temper (Figure 9). In particular, grog tempering is predominant in the Hedges Test Pit 1, and especially its lowest Stratum 21. There is an increase in the proportion of shell temper from lower to upper deposits in the Hedges Block Excavation area, and in the near-mound northeast excavation units at Hughes. This corresponds to an increased use of shell temper later in the occupations of both sites. The available dates from these two sites are somewhat at odds with this ceramic data. In particular, the radiocarbon date for the midden above Hedges Feature 4 is later than the archaeomagnetic date estimate for Feature 5, while the proportion of shell tempering is larger in the Feature 5 sample. The Hughes dates (from Feature 7/middle deposit and Features 8 and 16/lower deposit) fit with the stratigraphic relationship there, but the pre-1400 dates on the lower feature seem earlier than expected from the ceramics.

We examined decorated ceramic sherds using both type/variety and the descriptive classification systems. In the descriptive system, Classes A and B refer to predominantly incised or trailed line patterns (A has vertical or diagonal rectilinear patterns while $\mathrm{B}$ uses horizontal and curvilinear patterns). Class $\mathrm{C}$ refers to punctated decorations. Class D has brushing as the major decoration. Class $\mathrm{E}$ is engraved patterns; $\mathrm{F}$ has stamped decorations; $\mathrm{G}$ is reserved for slipped pottery; and Class $\mathrm{H}$ refers to appliqued, ridged, and noded decorations. Comparing decorative classes at the Hedges and Hughes ceramic assemblages (Figure 10), we find that small sherds with incised designs insufficient to differentiate as A or B are common at both sites. Class $\mathrm{C}$ (punctation) and Class D (brushing) are more heavily represented at Hughes than at Hedges. Engraved sherds (Class E) make up more of the Hedges assemblage (8 percent for Hedges, 3 percent for Hughes).

Some decorative patterns can be recognized as defined ceramic types from the Caddo area. For example, the Hedges Stratum 21 assemblage had many incised and punctated sherds, with grog (or occasionally grog+shell or shell) temper, with Class B rim (Beloit or Bethel) and body (Bard) patterns, identified as Military Road Incised jars (Early 1993:103). Common at both sites were rows of diagonal slash incising (Class A, 


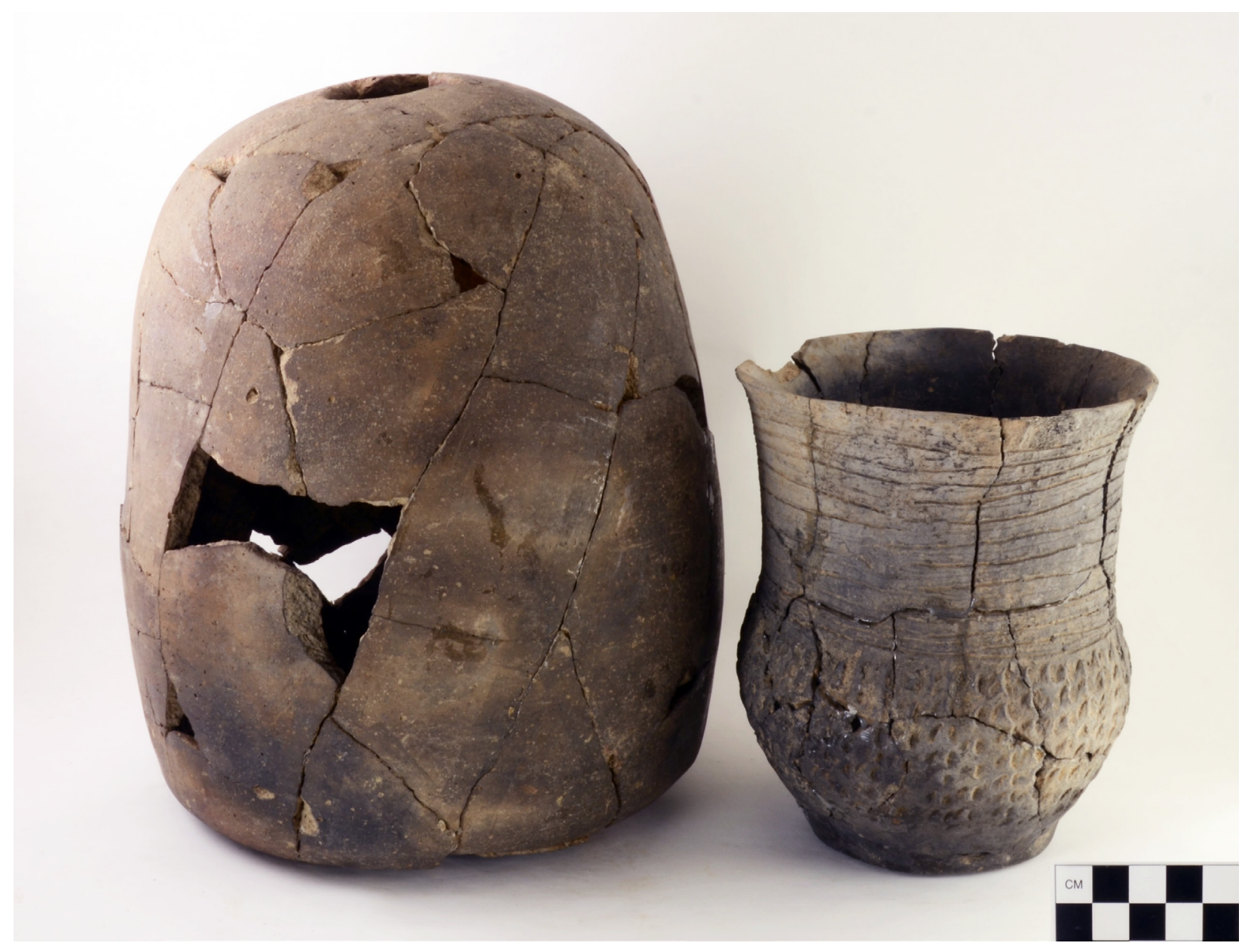

Figure 8. Reconstructed pots from Hedges Feature 1 structure floor (Arkansas Archeological Survey photograph).

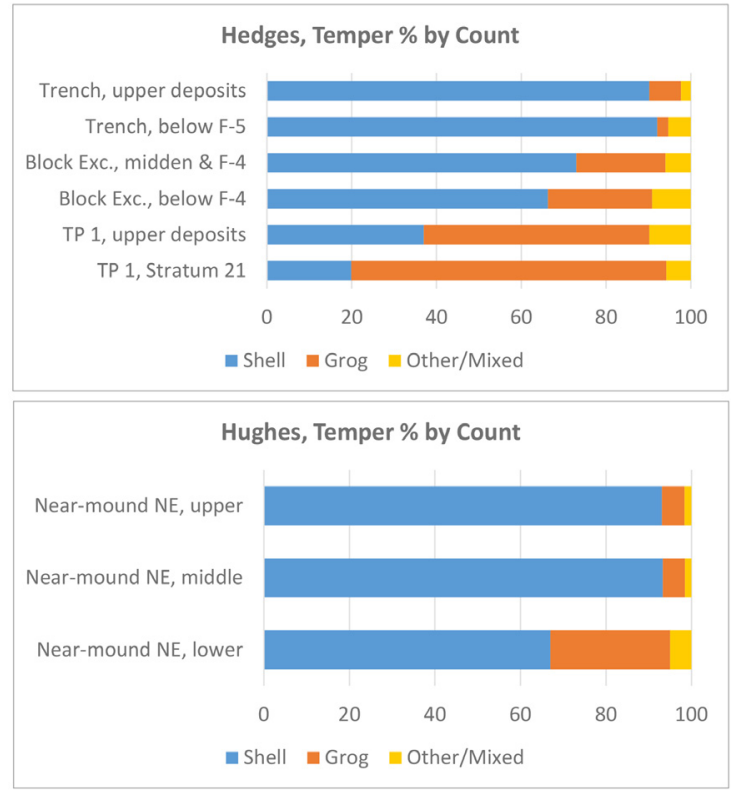

Figure 9. Stratigraphic comparison of ceramic tempers, showing increase in proportion of shell tempering through time (Hedges, $n=6501$ sherds; Hughes $n=3268$ sherds).

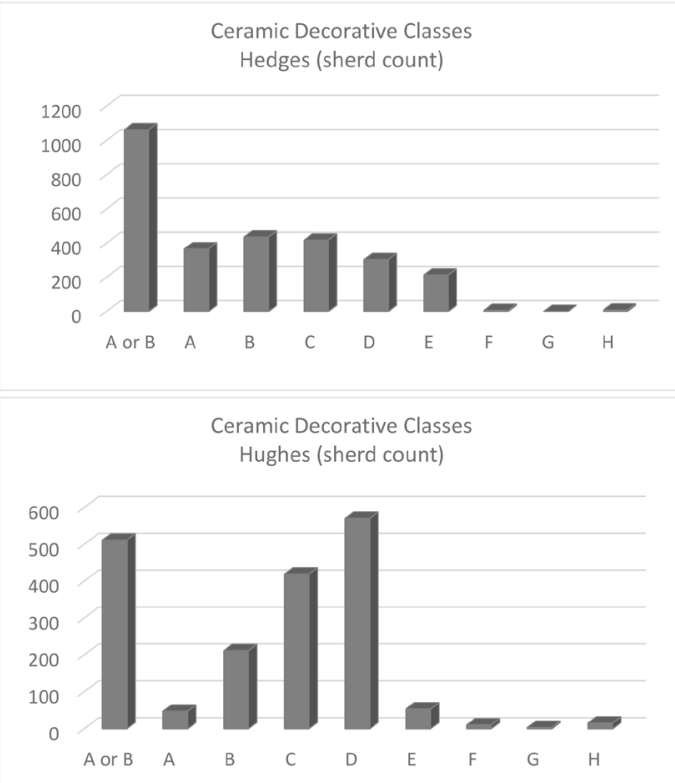

Figure 10. Comparison of ceramic decorative classes (Hedges, $\mathrm{n}=2810$ sherds, Hughes, $\mathrm{n}=1839$ sherds). 
Agnes or Alfred patterns) or punctations (Class C, Chattanooga pattern) on rims, and curvilinear trailing or incising and nodes on bodies (Class B, Babson, Baker, or Belmont patterns). At both sites, these sherds were tempered typically with shell or shell+grog. This combination of decoration and temper is characteristic of Foster Trailed-Incised jars (Early 1988:74-75; Schambach and Miller 1984:121-122). Other patterns seen on shell-tempered rims and bodies at both sites include the Chatham rim pattern common on Cowhide "Stamped" jars and the Caney body pattern often found on Caney Punctated jars. Engraved patterns included carinated bowl rims with Elaine, Elwyn, and Ezra patterns characteristic of Friendship Engraved var. Freeman and var. Meador and Cook Engraved types (Early 1993:87-90).

We can identify a number of types at the sites (Table 3), and the ceramic similarities indicate contemporaneous occupations at Hedges and Hughes. There are a few Woodland period sherds at Hughes, and a scatter of Middle Caddo period (East phase) sherds at both sites. There is a substantial Late Caddo period (Mid-Ouachita phase) deposit recognized in Stratum 21 at Hedges, with a light scatter of the same types at Hughes. The main occupation at both sites fits into the Late Caddo period. The Social Hill phase was defined in the middle Ouachita River valley in part based on the Hedges ceramics. Because of the similarities in the ceramics and other material culture, I anticipate extending the Social Hill phase into the Saline River valley.

The link between decorative patterns and temper recipes with ceramic types and varieties is less than straightforward. For example, we might sort small, brushed shell-tempered sherds as Grace Brushed or Mound Tract Incised and Brushed if we look from the perspective of southeast Arkansas, or as Karnack Brushed-Incised if we are thinking about Caddo types from southwest Arkansas. There were a few sherds found at Hughes that resemble ceramics from sites in the Arkansas and Mississippi river valleys. These include rim sherds with an appliqued "filleted" rim treatment similar to some Bell Plain bowls, two red-slipped shelltempered sherds identified as Old Town Red.

While we did not specifically compare coarse/ utilitarian wares versus fine wares during our analysis,

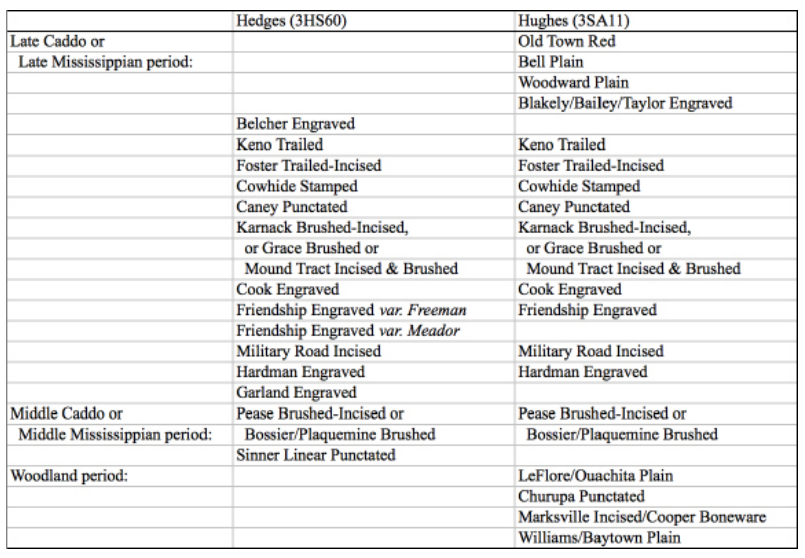

Table 3. Ceramic Types Identified at Hedges and Hughes.

Caddo potters used different decorative techniques on bowls, bottles, and jars. We can use decoration to infer vessel form. The prominence of incised, punctated, and brushed decorations shows a high proportion of utilitarian wares or jars in both assemblages. Relatively few bottles or fine ware vessel fragments were identified at either site. Sooting was not particularly prevalent, but I did note some large diameter jars represented by partial vessels at both sites. The two reconstructed vessels from the Feature 1 structure floor at Hedges is a reminder that whole vessels were sometimes left in structures (e.g., Harrington 1920:37-39), not just placed in graves.

\section{Community Patterning}

The Hedges and Hughes sites show similarities in their community patterns, as seen in the schematic views in Figure 11. Excavations at both sites uncovered residues of burned structures covered with midden next to the main mounds. Sequences of building, using, and terminating these near-mound structures created elevated areas beside the mounds that are visible on the topographic maps of the sites. Covering these burned structures with midden rich in organic debris, potsherds, and food bone represents a different pattern than the clean artifact-free earth used to bury mound structures.

Both sites have quantities of food remains (wellpreserved faunal collections) as well as hints of crafting activity (e.g., drills and drilled ornaments).

What is lacking from our pictures of these sites are the residential areas and houses that were near the mound centers. Remote sensing was not possible at Hughes because the property is now in woods and that 

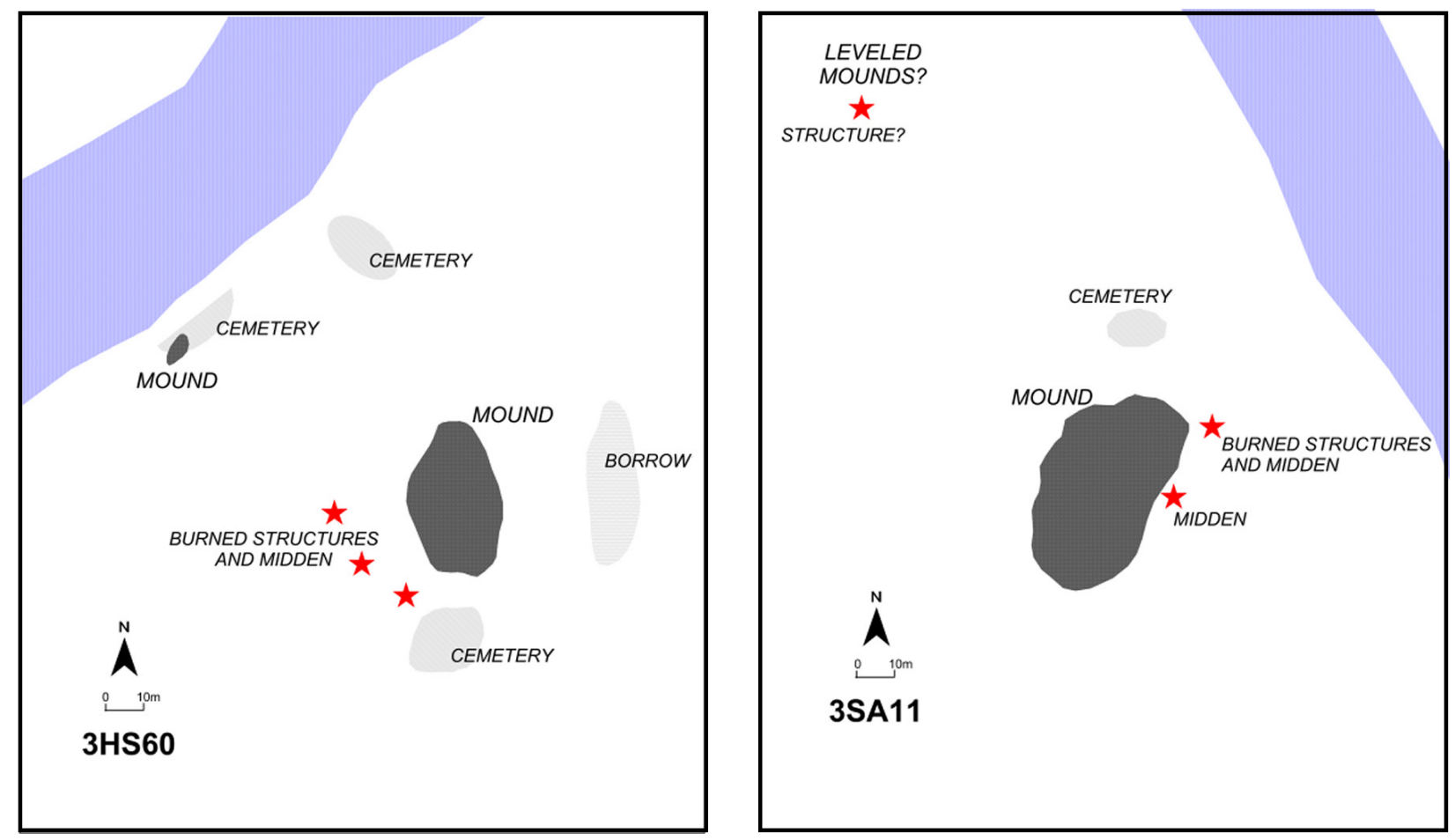

Figure 11. Schematic illustrations comparing community patterning at Hedges (3HS60) and Hughes (3SA11).

technology was in its infancy at the time of the Hedges excavations in the early 1970s, so we do not have the advantages of large-scale geophysical surveying (cf. McKinnon 2017:136). Neither did we have large-scale area excavations at these sites. We did do systematic shovel testing at Hughes, and there was limited auger testing to identify the presence of midden at Hedges. Anecdotal reports of digging by amateurs and collectors at both sites indicates cemetery areas near the mounds. We would expect residential areas and houses as well. Presumably, these would take the form of house clusters around the mound centers. One may be represented by the hearth (Feature 1) exposed on the north end of the Hughes site. If these ordinary houses were not burned (or were not smothered with dirt to preserve charred timbers), all that would be left would be a post pattern, difficult to detect without large excavation areas.

\section{Concluding Thoughts}

Interpretation of these two mound sites and their assemblages continues as I complete a monograph describing and comparing the archaeological investigations at these two ancestral Caddo communities. We are forming a picture of the physical configuration of the sites, the spatial layout of the communities, and the timing and patterning of activities that took place there. While there is earlier use of both sites, the main occupation at Hughes and Hedges took place between about A.D. 1450-1650. The artifacts show similarities, with ceramic types such as Foster TrailedIncised, Mound Tract Incised and Brushed, Cowhide Stamped, Grace Brushed, and Caney Punctated, and Bassett and Maud arrow points, found at both sites.

Excavations next to the mounds at Hughes and Hedges uncovered sequences of burned structures covered with midden containing quantities of ceramic sherds, chipped stone, charred wood, and food bone. While it is tempting to describe "special" feasting and crafting activities in these near-mound locations, it is difficult to make the argument without comparisons with midden from ordinary houses. The quantities of faunal material in the excavated midden deposits at both sites, however, reminds us that we need to pay more attention to analysis of preserved food remains from sites like these. At the Arkansas Archeological Survey, for example, we have curated collections from older excavations that include charred food plants and animal bone from structure contexts. These await a larger comparative study. 


\section{Acknowledgments}

Thanks to Arkansas Archeological Survey

Henderson State University Research Station assistants

Kate Wright, Matt Reynolds, Vanessa Hanvey, and

Chelsea Cinotto for preliminary artifact analyses and for artifact photography. Ann Early provided details about fieldwork at Hedges. Lucretia Kelly analyzed a sample of faunal material from Hughes. Elizabeth Horton identified the corn used in the Hedges AMS date. A grant from the Arkansas Archeological Society's Archeological Research Fund funded the Hedges AMS date. An HSU faculty research grant that funded the C14 dating from Hughes. Funding for the Hughes faunal analysis came from the State of Arkansas. I appreciate the Arkansas Archeological Society volunteers and Henderson State University students (Mary Ann Goodman, Florence Davis, Judy Thye, Sue Crane, Tony Caver, Cheryl Jerrels, Lyn Welland, Janice Fisher, Denise Evans, Natasha Johnson, James Allen, Turell Williams, KaJuan Watson, and Drew Wright) who helped with artifact analyses in 2011 and 2017. Artifacts from both excavations are curated at the Arkansas Archeological Survey's HSU Research Station in Arkadelphia (Accessions 1973-540, 1974-746, and 2002-414).

\section{References Cited}

Early, Ann M.

1974 Winter Archeology, the Hedges Site, 3HS60. Field Notes, Newsletter of the Arkansas Archeological Society 116:3-5.

1988 Standridge: Caddoan Settlement in a Mountain Environment. Research Series No. 29. Arkansas Archeological Survey, Fayetteville.

2002 Arkansas Prehistory and History in Review: The Social Hill Phase. Field Notes, Newsletter of the Arkansas Archeological Society 306:10-13.

Early, Ann M. (editor)

1993 Caddoan Saltmakers in the Ouachita Valley: The Hardman Site. Research Series No. 43. Arkansas Archeological Survey, Fayetteville.
Harrington, M. R.

1920 Certain Caddo Sites in Arkansas. Indian Notes and Monographs Series. Museum of the American Indian, Heye Foundation, New York.

Jeter, Marvin D.

1990 Edward Palmer's Arkansaw Mounds. University of Arkansas Press, Fayetteville.

Kay, Marvin

1984 Late Caddo Subtractive Technology in the Red River Basin. In Cedar Grove: An Interdisciplinary Investigation of a Late Caddo Farmstead in the Red River Valley, edited by Neal L. Trubowitz, pp. 174-206. Research Series No. 23. Arkansas Archeological Survey, Fayetteville.

Kelley, David B. (editor)

1997 Two Caddoan Farmsteads in the Red River Valley: The Archeology of the McLelland and Joe Clark Sites. Research Series No. 51. Arkansas Archeological Survey, Fayetteville.

McKinnon, Duncan P.

2017 The Battle Mound Landscape: Exploring Space, Place, and History of a Red River Caddo Community in Southwest Arkansas. Research Series No. 68. Arkansas Archeological Survey, Fayetteville.

Perttula, Timothy K.

2017 Caddo Landscapes in the East Texas Forests. American Landscapes series, Oxbow Books, Havertown, Pennsylvania.

Perttula, Timothy K, Mary Beth Trubitt, and Jeffrey S. Girard

2011 The Use of Shell-Tempered Pottery in the Caddo Area of the Southeastern United States. Southeastern Archaeology 30(2):242-267. 
Schambach, Frank F., and John E. Miller

1984 A Description and Analysis of the Ceramics. In Cedar Grove: An Interdisciplinary Investigation of a Late Caddo Farmstead in the Red River Valley, edited by Neal L. Trubowitz, pp. 109-170. Research Series No. 23. Arkansas Archeological Survey, Fayetteville.

Thomas, Cyrus

1894 Report on the Mound Explorations of the Bureau of Ethnology. 12th Annual Report. Bureau of Ethnology, Washington, DC.

Trubitt, Mary Beth

2009 Burning and Burying Buildings: Exploring Variation in Caddo Architecture in Southwest Arkansas. Southeastern Archaeology 28(2):233247.

2012a A Fresh Look at the Hedges Site. Field Notes, Newsletter of the Arkansas Archeological Society 367:8-12.

2012b Caddo in the Saline River Valley of Arkansas: The Borderlands Project and the Hughes Site. In The Archaeology of the Caddo, edited by Timothy K. Perttula and Chester P. Walker, pp. 288-312. University of Nebraska Press, Lincoln.
Webb, Clarence $\mathrm{H}$.

1959 The Belcher Mound: A Stratified Caddoan Site in Caddo Parish, Louisiana. Memoirs No. 16. Society for American Archaeology, Salt Lake City, Utah.

Wolfman, Daniel

1982 Archeomagnetic Dating in Arkansas and the Border Areas of Adjacent States. In Arkansas Archeology in Review, edited by Neal L. Trubowitz and Marvin D. Jeter, pp. 277-300. Research Series No. 15. Arkansas Archeological Survey, Fayetteville.

Wolfman, Daniel

1990 Archaeomagnetic Dating in Arkansas and the Border Areas of Adjacent States - II. In Archaeomagnetic Dating, edited by Jeffrey L. Eighmy and Robert S. Sternberg, pp. 237-260. University of Arizona Press, Tucson. 